http://jmscr.igmpublication.org/home/ ISSN (e)-2347-176x ISSN (p) 2455-0450

crossref DOI: https://dx.doi.org/10.18535/jmscr/v10i1.16

\author{
Journal Of Medical Science And Clinical Research \\ IGM Publication \\ An Official Publication of IGM Publication
}

\title{
Comparative Study of Functional Outcome of Dynamic Compression Plating With Interlocking Nailing For Fracture Shaft of Humerus in Adult
}

\author{
Authors \\ Dr Himanshu Hemant ${ }^{1}$, Dr Rajesh Kumar ${ }^{2}$ \\ ${ }^{1}$ Junior Resident, Department of Orthopaedics, KMC, Katihar \\ ${ }^{2}$ Assistant Professor KMC, Katihar
}

\begin{abstract}
Introduction: Humerus fracture is a common but difficult to manage in orthopedics. These are usually managed non-operatively (with a hanging arm cast, $U$ cast or a $U$ slab) unless complicated. Fractures of the shaft of the humerus account for around 1\% to 2\% of all bone fractures, and $14 \%$ of humeral fractures. ${ }^{[5]}$ The majority of humeral fractures do not require surgery and can be managed with a functional orthosis. The purpose of this study is to compare the outcomes of dynamic compression plating with interlocking nailing for the fracture shaft of humerus and to analyse statistically significant difference in the results of these two methods.

Method: The study was prospective, randomize, comparative study. In which 30 patients were divided into two groups. Group 1- Plating (open reduction and internal fixation with dynamic compression plating and Group 2- Intra medullary nailing (closed reduction and inernal fixation with antigrade intramedullary interlocking nail) for surgical management of fracture of humerus diaphysis and to find the functional outcome between dynamic compression plating $(D C P)$ and intramedullary interlocking nailing in diaphysis fracture of humerus in adult.

Result: In the present study it is observed that the DCP group takes less time for union $(p=0.013)$ as compare to interlocking group. In DCP group-excellent cases were $73.03 \%$, good cases-13.3\%, fair and poor were $6.7 \%$. In interlocking nailing group excellent cases were- $46.7 \%$, good cases- $26.7 \%$, fair cases$16.6 \%$ and poor was $10 \%$ and the $p$ value $=0.03$. post operative complication like impingement and shoulder pain were more common in interlocking nailing and implant failure (6.7\%) was found in DCP.

Conclusion: We conclude that antegrade intramedullary interlocking nails are better for transverse humerus shaft fractures, while plating is preferable for comminuted humerus shaft fractures and instances with accompanying neuro-vascular or soft tissue injuries. There is no one fixing mechanism that is preferable in all conditions for acute diaphyseal fractures, thus each patient must be treated individually. Although there appears to be significant difference in radiological union or rate of union between the two groups, plating of humerus shaft fractures is a favorable fixation approach based on complications reported and functional outcomes noted.
\end{abstract}

\section{Introduction}

Humerus fracture is a common but difficult to manage in orthopedics. These are usually managed non-operatively (with a hanging arm cast, U cast or a U slab) unless complicated. Since there is a thick covering of muscles and blood vessels on the bone, complete union is not always required. It is usually diaphyseal, and surgery is 
only indicated in case of non-union, neurovascular injuries, pathological, or open fractures, most common being multiple injuries. ${ }^{[1-4]}$

Fractures of the shaft of the humerus account for around $1 \%$ to $2 \%$ of all bone fractures, and $14 \%$ of humeral fractures. ${ }^{[5]}$ It has a bimodal incidence, with a first peak in the third decade of life, predominantly in males, owing to high energy trauma, and a second rise in the sixth decade in women, due to minor trauma.

The majority of humeral fractures do not require surgery and can be managed with a functional orthosis. External fixators, compression plating (ORIF / MIPPO), and intra-medullary nails (flexible/rigid, antegrade/retrograde nailing) are all alternatives available to the surgeon in these instances. The benefits of open reduction and internal fixation using a dynamic compression plate (DCP) are as follows:

- This is a method of achieving a direct open reduction and stable fixation without violation of rotator cuff.

- Facilitates identification, exploration and preservation of radial nerve.

- As there is no need for C- arm the medical staff has no radiation hazards.

- The limb can be mobilized early \& joint stiffness as well as muscle contractures can be minimized.

Closed reduction and internal fixation with Intramedullary Inter Locking Nail (ILN) has following advantages:

- Minimal surgical intervention (so less soft tissue damage, less infection and less radial nerve palsies)

- Load sharing implant. ${ }^{[6]}$

- Biological fixation

- Rotational and torsional stability

- Early mobilization

The purpose of this study is to compare the outcomes of each method of fixation (dynamic compression plating and interlocking nailing) for the fracture shaft of humerus and to analyse statistically significant difference in the results of these two methods.

\section{Aims and Objectives}

To find the difference between the functional outcome between the dynamic compression plating (DCP) and the intramedullary interlocking nailing in diaphyseal fractures of the humerus in adults, as measured by the DASH questionnaire, the mean duration of union and associated complications.

\section{Material and Methods}

The study was prospective, randomize, comparative study done at department of orthopaedics KMCH Katihar, in which 30 patients where divided into two groups. Group 1- Plating (open reduction and internal fixation with dynamic compression plating) and Group 2- Intra medullary nailing (closed reduction and inernal fixation with antigrade intramedullary interlocking nail) for surgical management of fracture of humerus diaphysis and to find the functional outcome between dynamic compression plating (DCP) and intramedullary interlocking nailing in diaphysis fracture of humerus in adult having exclusion criteria Fracture of upper and lower ends of humerus, Patients treated with other than dynamic compression plate or interlocking nail, Patients with pre existing shoulder and elbow problems, Pathological fractures, Patients who were lost to follow up or died before the fracture union.

After approval from Institutional Ethical Committee all of the 30 cases were examined with a complete history, clinical examination to determine the type of the fracture, and a standard examination consisting of an anteroposterior and lateral radiograph of the afflicted arm. Radial nerve damage was noted whether it was present or not. The fracture was temporarily immobilized with the use of a U-slab and an arm pouch.

\section{Follow up and criteria for evaluation}

Clinical examinations were performed at each follow-up appointment to examine surgical wound healing, discomfort, tenderness at the fracture site with free shoulder and elbow movement, fracture stability, and clinical union. When the fracture site 
was stable and pain-free, the clinical union was confirmed. At each follow-up appointment, Xrays were performed to check fracture union.

It was recorded how long it took for clinical and radiological union. The fracture was classified as delayed union if no clinical or radiological evidence of union were observed by 16 weeks after injury, and nonunion if no clinical or radiological signs of union were found by 32 weeks following injury.

Following the patient rehabilitation regimen, shoulder, elbow, forearm, and wrist exercises were performed according to the state of fracture union and time since surgery. Patients were told not to move heavy objects or put stress on the injured leg. Patients were tracked until radiological union was established.

\section{Functional Outcome}

Patients in the plating and intramedullary nailing groups were followed up on every month for up to 28 weeks until radiological union was verified. Union was defined as the absence of functional pain and local tenderness at the fracture site, as well as the presence of bridging callus in three of the four cortices on AP and lateral views. The time taken for union in both groups was documented, and the functional outcomes in both groups were compared. At each follow-up, complications such as malunion, non-union, nerve damage, residual deformity, and infections were noted. In each of these groups, the functional result was assessed using the "Disabilities of arm, shoulder, and hand (DASH)" Questionnaire at 6 months or at complete recovery, whichever came first. ${ }^{[7]}$ The American Academy of Orthopaedic Surgeons (AAOS) established the Dash scoring system, which has been verified by multiple studies. ${ }^{[8,9]}$ It is a highly effective instrument for monitoring upper limb function. The DASH questionnaire consists of thirty self-reported items with responses ranging from 1 to 5 points. The scale ranges from 0 to 100 . A higher score suggests a greater degree of impairment.

\section{Statistical Analysis}

Data was checked for accuracy and completeness then coded and entered into (Statistical Package for the Social Sciences) version 21.0 for analysis. The results presented in frequency tables, cross tabulations and figures. Categorical data are presented as frequency with percentages. Continuous data with normal distribution are presented as mean with standard deviation. $t$ test and Chi-square or Fisher Exact test has been used to find the significance of study parameters on categorical scale between two groups. A $p$-values $<0.05$ were considered significant.

\section{Results and Analysis}

Table: 1 Distribution of study population according to surgical treatment. $(n=30)$

\begin{tabular}{|l|c|c|}
\hline Surgical Treatment & No of Cases & Percentage \\
\hline Dynamic compression plating & 15 & 50.0 \\
\hline Intramedullary nailing & 15 & 50.0 \\
\hline Total & 30 & 100.0 \\
\hline
\end{tabular}

Table: 2 Age Distribution among study population. $(n=30)$

\begin{tabular}{|c|c|c|c|c|c|c|}
\hline \multirow[t]{2}{*}{ Age in Year } & \multicolumn{2}{|c|}{$\begin{array}{c}\text { Dynamic compression } \\
\text { plating }(\mathrm{n}=15)\end{array}$} & \multicolumn{2}{|c|}{$\begin{array}{c}\text { Interlocking } \\
\text { nailing (n=15) }\end{array}$} & \multicolumn{2}{|c|}{$\operatorname{Total}(\mathbf{n}=30)$} \\
\hline & No & $\%$ & No & $\%$ & No & $\%$ \\
\hline $18-20$ & 7 & 46.7 & 6 & 40.0 & 13 & 43.4 \\
\hline $21-40$ & 4 & 26.7 & 3 & 20.0 & 07 & 23.3 \\
\hline $41-60$ & 3 & 20.0 & 4 & 26.7 & 07 & 23.3 \\
\hline$>60$ & 1 & 6.6 & 2 & 13.3 & 03 & 10.0 \\
\hline Total & 15 & 100 & 15 & 100.0 & 30 & 100 \\
\hline Mean \& SD Value & \multicolumn{2}{|c|}{$30.53 \pm 14.82$} & \multicolumn{2}{|c|}{$36.26 \pm 17.28$} & \multicolumn{2}{|c|}{$33.40 \pm 16.08$} \\
\hline P Value & \multicolumn{4}{|c|}{0.387} & & \\
\hline
\end{tabular}


Table: 3 Sex distribution among study population $(n=30)$

\begin{tabular}{|l|c|c|c|c|c|c|}
\hline \multirow{2}{*}{ Sex } & \multicolumn{2}{|c|}{$\begin{array}{c}\text { Dynamic compression } \\
\text { plating(n=15) }\end{array}$} & \multicolumn{2}{c|}{$\begin{array}{c}\text { Interlocking } \\
\text { nailing (n=15) }\end{array}$} & \multicolumn{2}{c|}{ Total(n=30) } \\
\cline { 2 - 7 } & No & $\%$ & No & $\%$ & No & $\%$ \\
\hline Male & 9 & 60.0 & 8 & 53.3 & 17 & 56.7 \\
\hline Female & 6 & 40.0 & 7 & 46.7 & 13 & 43.3 \\
\hline Total & 15 & 100 & 15 & 100.0 & 30 & 100 \\
\hline $\begin{array}{l}\text { Statistical } \\
\text { Analysis }\end{array}$ & \multicolumn{3}{|c|}{$\begin{array}{c}\text { Chi-square- } 0.1357 \\
\text { P Value- } 0.712\end{array}$} & & \\
\hline
\end{tabular}

Table: 4 Mode of Injury

\begin{tabular}{|l|c|c|c|c|c|c|}
\hline \multirow{2}{*}{ Mode of Injury } & \multicolumn{2}{|c|}{$\begin{array}{c}\text { Dynamic compression } \\
\text { plating(n=15) }\end{array}$} & \multicolumn{2}{c|}{$\begin{array}{c}\text { Interlocking } \\
\text { nailing (n=15) }\end{array}$} & \multicolumn{2}{c|}{ Total(n=30) } \\
\cline { 2 - 7 } & No & $\%$ & No & $\%$ & No & $\%$ \\
\hline RTA & 04 & 26.7 & 05 & 33.3 & 09 & 30.0 \\
\hline FALL & 11 & 73.3 & 10 & 66.7 & 21 & 70.0 \\
\hline Total & 15 & 100 & 15 & 100.0 & 30 & 100 \\
\hline $\begin{array}{l}\text { Statistical } \\
\text { Analysis }\end{array}$ & \multicolumn{3}{|c|}{$\begin{array}{c}\text { Chi-square- } 0.1587 \\
\text { P Value- } 0.690\end{array}$} & & \\
\hline
\end{tabular}

Table: 5 Side of Injury $(n=30)$

\begin{tabular}{|l|c|c|c|c|c|c|}
\hline \multirow{2}{*}{ Side of Injury } & \multicolumn{2}{|c|}{$\begin{array}{c}\text { Dynamic compression } \\
\text { plating(n=15) }\end{array}$} & \multicolumn{2}{c|}{$\begin{array}{c}\text { Interlocking } \\
\text { nailing (n=15) }\end{array}$} & \multicolumn{2}{c|}{ Total(n=30) } \\
\cline { 2 - 7 } & No & $\%$ & No & $\%$ & No & $\%$ \\
\hline Right & 12 & 80.0 & 11 & 73.3 & 23 & 76.7 \\
\hline Left & 03 & 20.0 & 04 & 26.7 & 07 & 23.3 \\
\hline Total & 15 & 100 & 15 & 100.0 & 30 & 100 \\
\hline $\begin{array}{l}\text { Statistical } \\
\text { Analysis }\end{array}$ & \multicolumn{4}{|c|}{$\begin{array}{c}\text { Chi-square- } 0.1863 \\
\text { P Value- } 0.665\end{array}$} & & \\
\hline
\end{tabular}

Table: 6 Associated Injury. $(n=30)$

\begin{tabular}{|l|c|c|c|c|c|c|}
\hline \multirow{2}{*}{ Associated Injury } & \multicolumn{2}{|c|}{$\begin{array}{c}\text { Dynamic compression } \\
\text { plating(n=15) }\end{array}$} & \multicolumn{2}{c|}{$\begin{array}{c}\text { Interlocking } \\
\text { nailing (n=15) }\end{array}$} & \multicolumn{2}{c|}{ Total(n=30) } \\
\cline { 2 - 7 } & No & $\%$ & No & $\%$ & No & $\%$ \\
\hline Clavicle fracture & 01 & 6.7 & 00 & 00 & 01 & 3.3 \\
\hline Ribs fracture & 02 & 13.3 & 01 & 6.7 & 03 & 10.0 \\
\hline Forearm fracture & 00 & 00 & 01 & 6.7 & 01 & 3.3 \\
\hline Compound injury & 01 & 6.7 & 01 & 6.7 & 02 & 6.6 \\
\hline Total & 4 & 26.7 & 3 & 20.0 & 07 & 23.3 \\
\hline Statistical analysis & \multicolumn{3}{|c|}{$\begin{array}{c}\text { Chi-square- 2.2361 } \\
\text { P Value- 0.524 }\end{array}$} \\
\hline
\end{tabular}

Table: 7 Time taken for fracture union

\begin{tabular}{|l|c|c|c|c|c|c|}
\hline \multirow{2}{*}{$\begin{array}{l}\text { Union Time } \\
\text { (Weeks) }\end{array}$} & \multicolumn{2}{|c|}{$\begin{array}{c}\text { Dynamic compression } \\
\text { plating(n=15) }\end{array}$} & \multicolumn{2}{|c|}{$\begin{array}{c}\text { Interlocking } \\
\text { nailing }(\mathbf{n}=15)\end{array}$} & \multicolumn{2}{|c|}{ Total(n=30) } \\
\cline { 2 - 7 } & Mean & SD & Mean & SD & Mean & SD \\
\hline $\begin{array}{l}\text { Time taken } \\
\text { for Union }\end{array}$ & 19.60 & \pm 2.74 & 23.86 & \pm 1.59 & 21.73 & 3.09 \\
\hline $\begin{array}{l}\boldsymbol{t} \text { test } \\
\text { p Value }\end{array}$ & 0.007 & & & & & \\
\hline
\end{tabular}


Figure: 1 Time taken for fracture union

\section{Time taken for Union}

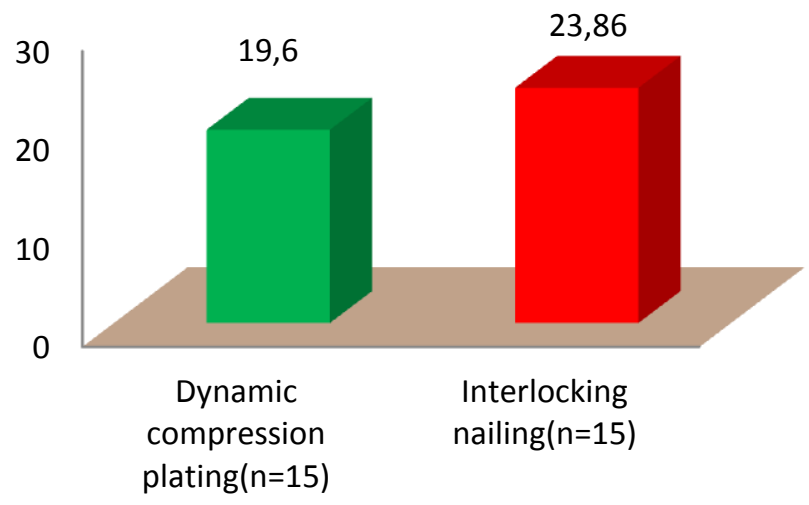

Dynamic compression plating $(n=15)$

Interlocking nailing( $n=15)$
The Dynamic compression plating group was found a minimum time for union i.e. 16 weeks and maximum 24 weeks with a mean \& SD time for union was $19.60 \pm 2.74$ weeks and for Interlocking nailing group union time was 20 weeks minimum and 26 weeks maximum with a mean \& SD time was $23.86 \pm 1.59$ weeks. The mean average union time was $21.73 \pm 3.09$ weeks. We have found significant $\mathrm{p}$ value -0.013 .

Table: 8 Final outcomes (Comparison of DASH score)

\begin{tabular}{|l|c|c|c|c|c|c|}
\hline \multirow{2}{*}{ Final outcome } & \multicolumn{2}{|c|}{$\begin{array}{c}\text { Dynamic compression } \\
\text { plating(n=15) }\end{array}$} & \multicolumn{2}{c|}{$\begin{array}{c}\text { Interlocking } \\
\text { nailing }(\mathbf{n = 1 5})\end{array}$} & \multicolumn{2}{c|}{ Total(n=30) } \\
\cline { 2 - 7 } & No & $\%$ & No & $\%$ & No & $\%$ \\
\hline Excellent & 11 & 73.3 & 03 & 20.0 & 14 & 46.7 \\
\hline Good & 02 & 13.3 & 06 & 40.0 & 08 & 26.7 \\
\hline Fair & 01 & 6.7 & 04 & 26.7 & 05 & 16.6 \\
\hline Poor & 01 & 6.7 & 02 & 13.3 & 03 & 10.0 \\
\hline Total & 15 & 100 & 15 & 100.0 & 30 & 100 \\
\hline $\begin{array}{l}\text { Statistical } \\
\text { analysis }\end{array}$ & \multicolumn{7}{|c|}{$\begin{array}{c}\text { Chi-square- 8.7047 } \\
\text { P Value- } 0.03\end{array}$} \\
\hline
\end{tabular}

Figure: 2 Final outcomes (Comparison of DASH score)

\section{Final outcome}

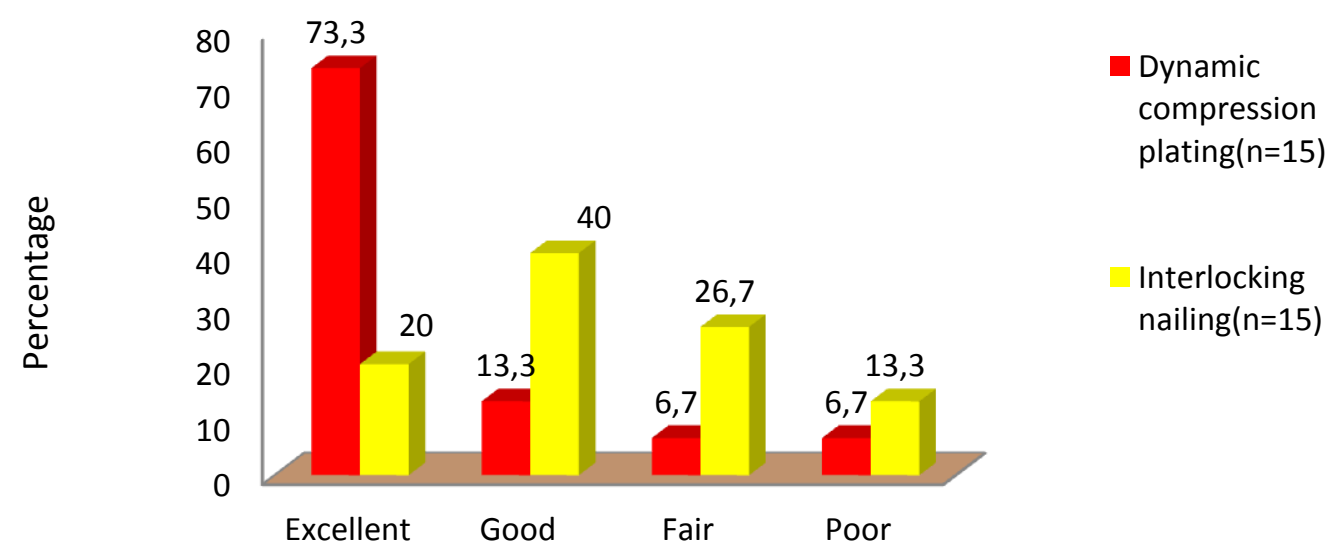


We found that the final outcome in between the groups, comparison of DASH score, maximum number of excellent cases were Dynamic compression plating group. i.e. 73.03\%, good$13.3 \%$, Fair \& poor was $6.7 \%$ respectively. In another Interlocking nailing group excellent cases were found $46.7 \%$, good- $26.7 \%$, fair- $16.6 \%$ and poor was $10.0 \%$ respectively. We have found statistically significant $\mathrm{p}$ value -0.03 .

Table: 9 Post operative Complications

\begin{tabular}{|l|c|c|c|c|c|c|}
\hline \multirow{2}{*}{$\begin{array}{l}\text { Post operative } \\
\text { Complications }\end{array}$} & $\begin{array}{c}\text { Dynamic compression } \\
\text { plating(n=15) }\end{array}$ & \multicolumn{2}{c|}{$\begin{array}{c}\text { Interlocking } \\
\text { nailing (n=15) }\end{array}$} & \multicolumn{2}{c|}{ Total(n=30) } \\
\cline { 2 - 7 } & No & $\%$ & No & $\%$ & No & $\%$ \\
\hline Impingement & 00 & 00 & 04 & 26.7 & 04 & 13.3 \\
\hline Implant failure & 01 & 6.7 & 00 & 00 & 01 & 3.3 \\
\hline Radial nerve injury & 01 & 6.7 & 00 & 00 & 01 & 3.3 \\
\hline Shoulder Pain & 00 & 00 & 02 & 13.3 & 02 & 6.7 \\
\hline Shoulder stiffness & 00 & 00 & 02 & 13.3 & 02 & 6.7 \\
\hline Superficial infection & 00 & 00 & 00 & 00 & 00 & 00 \\
\hline Total & 02 & 13.4 & 08 & 53.3 & 10 & 33.3 \\
\hline Statistical analysis & \multicolumn{3}{|c|}{$\begin{array}{c}\text { Chi-square- 10.000 } \\
\text { P Value- } 0.04\end{array}$} \\
\hline
\end{tabular}

Impingement, Shoulder stiffness \& Shoulder Pain were most post operative complications in Interlocking nailing group, i.e. $26.7 \%$. \& 13.3\% both respectively. One (6.7\%) Implant failure case was found in Dynamic compression plating groups. Over all low postoperative complication was found in Dynamic compression plating group. With significant $\mathrm{p}$ value- 0.04 .

\section{Discussion}

The patients with an acute humeral shaft fracture in adults admitted and treated in the Orthopaedic Ward of Katihar Medical College \& Hospital, in Bihar, during the period of December 2019 to July 2021. The study group were prospectively randomized into two categories. Plating (open reduction and internal fixation with dynamic compression plating-15 cases) group and Intramedullary nailing (close reduction and internal fixation with antegrade intramedullary interlocking nail-15 cases) group for surgical management of fracture of the humeral diaphysis. To confirm the diagnosis, all of the $\mathbf{3 0}$ cases were examined with a complete history, clinical examination to determine the type of the fracture, and a standard examination consisting of an anteroposterior and lateral radiograph of the afflicted arm.
The indications for open reduction and internal fixation of acute fractures of the humeral shaft have been described as: fractures in patients with multiple injuries; open fractures; fractures associated with vascular or neural injuries or with lesions of the shoulder, elbow or forearm in the same limb; bilateral upper extremity injuries; fractures for which closed methods of treatment have failed and pathological fractures. In several reported series the presence of associated multiple injuries was the most frequent indication for internal fixation of the humeral shaft, ${ }^{[20]}$ in our study associated multiple injuries and accidental fall were most common indications.

In this study, Majority of the cases was associated with ribs fracture, i.e. 10.0\%, compound injury was $6.6 \%$, both Clavicle and forearm fracture was $3.3 \%$. We have found no significant $\mathrm{p}$ value 0.524 .

In this study, the Dynamic compression plating group was found a minimum time for union i.e. 16 weeks and maximum 24 weeks with a mean \& SD time for union was 19.60 \pm 2.74 weeks and for Interlocking nailing group union time was 20 weeks minimum and 26 weeks maximum with a mean \& SD time was $23.86 \pm 1.59$ weeks. The mean average union time was $21.73 \pm 3.09$ weeks. We have found significant $\mathrm{p}$ value -0.013 . 


\begin{tabular}{|l|c|c|c|}
\hline Methods & Study series & Year & Time \\
\hline \multirow{4}{*}{ Plating } & Foster R $\mathrm{J}^{[10]}$ & 1985 & 14 weeks \\
\cline { 2 - 4 } & Singh $\mathrm{P}^{[1]]}$ & 2016 & 12.22 weeks \\
\cline { 2 - 4 } & Present study $^{\text {Nailing }}$ & 2021 & $\mathbf{1 9 . 6 0}$ weeks \\
\cline { 2 - 4 } & ${\text { Lin J } \mathbf{J}^{[12]}}^{[1]]}$ & 1998 & $\mathbf{8 . 6}$ weeks \\
\cline { 2 - 4 } & Singh $\mathrm{P}^{[1]}$ & $\mathbf{2 0 1 6}$ & $\mathbf{1 1}$ weeks \\
\cline { 2 - 4 } & Present study & $\mathbf{2 0 2 1}$ & $\mathbf{2 3 . 8 6}$ weeks \\
\hline
\end{tabular}

In this study, we found that the final outcome in between the groups, comparison of DASH score, maximum number of excellent cases were Dynamic compression plating group. i.e. $73.03 \%$, good-13.3\%, Fair \& poor was $6.7 \%$ respectively. In another Interlocking nailing group excellent cases were found $46.7 \%$, good- $26.7 \%$, fair- $16.6 \%$ and poor was $10.0 \%$ respectively. We have found statistically significant $\mathrm{p}$ value -0.03 .

Naveen $\mathbf{P}$ et $\mathbf{a l}^{[13]}$ found the average DASH score of the whole series was 36.614 / 100 (Lower the score better the function). The average DASH score in the DCP group was 24.666 and in the interlocking nailing group it was 48.562 . As the $P$ value is $0.010 \quad(<0.05)$, the results were statistically significant with respect to DASH score in both the groups. Among 34 patients, 11 had excellent results, 9 had good, 8 had fair and 6 had poor results. Among the 11 patients with excellent results, 6 patients were treated by dynamic compression plating and 5 were treated by interlocking nailing. Among the 9 patients with good results, 5 patients were treated by dynamic compression plating and 4 were treated by interlocking nailing. Among the 8 patients with fair results, 5 were treated by dynamic compression plating and 3 were treated by interlocking nailing and lastly the 6 patients with poor results, 2 belong to the dynamic compression plating group, 4 patients belong to interlocking nailing group. On statistical analysis, $\mathrm{P}$ value is $0.010(<0.05$, significant $)$ and also taking percentage into consideration, the dynamic compression plating group showed better results than the interlocking nailing group.

In the DCP group the incidence of post- operative radial nerve palsy is $2 \%$ to $5 \%,{ }^{[14]}$ but there were no such cases in our study. Which was same in the case of the interlocking group. The incidence of post-operative radial nerve palsy in various studies varies from $2.6 \%$ to $14.3 \% .^{[15,16]}$

Persistent pain after antegrade nailing is common. ${ }^{[17,18]}$ Habernek and Orthner21 in 1991 reported good results with Seidel's interlocking nail but later withdrew their support in 1998, as they had not assessed the shoulder functions of their patients properly. The cause of pain could be disruption of the rotator cuff in its avascular zone within $1 \mathrm{~cm}$ of its insertion to the greater tuberosity that may lead to poor healing.

In this study found, Impingement, Shoulder stiffness \& Shoulder Pain were most post operative complications in Interlocking nailing group, i.e. $26.7 \%$. \& $13.3 \%$ both respectively. One $(6.7 \%)$ Implant failure case was found in Dynamic compression plating groups. Over all low postoperative complication was found in Dynamic compression plating group. With significant $\mathrm{p}$ value-0.04.

Study of K Mohan et al ${ }^{[19]}$, out of 15 patients treated with dynamic compression plate, 14 patients had good range of movements at the shoulder and elbow, but 1 patient developed stiffness of shoulder joint. In 15 patients treated with interlocking nail, 11 patients had good range of movements at shoulder and elbow, 4 patients had stiffness at shoulder and 1 of them had elbow stiffness also. In those 4 cases, 2 are comminuted fractures and we immobilized the patient's arm for longer duration than the other cases (due to delay in union) Our results regarding range of mobility at shoulder and elbow joints are comparable with those of Bell's and Pratap Singh's study ${ }^{[20,11]}$

\section{Conclusion}

We conclude that antegrade intramedullary interlocking nails are better for transverse humerus shaft fractures, while plating is 
preferable for comminuted humerus shaft fractures and instances with accompanying neurovascular or soft tissue injuries. There is no one fixing mechanism that is preferable in all conditions for acute diaphyseal fractures, thus each patient must be treated individually. Although there appears to be significant difference in radiological union or rate of union between the two groups, plating of humerus shaft fractures is a favorable fixation approach based on complications reported and functional outcomes noted.

\section{References}

1. Walker M, Palumbo B, Badman B, Brooks J, Van Gelderen J, Mighell M. Humeral shaft fractures: A review. J Shoulder Elbow Surg. 2011; 20(5):833-44.

2. Zhao JG, Wang J, Wang C, Kan SL. Intramedullary nail versus plate fixation for humeral shaft fractures: A systematic review of overlapping meta-analyses. Medicine (Baltimore). 2015; 94(11):e599.

3. Duygun F, Aldemir C. Is locked compressive intramedullary nailing for adult humerus shaft fractures advantageous?. Eklem hastaliklari ve cerrahisi. 2017; 28(2):80-6.

4. Puri SR, Biswas SK, Salgia A, Sanghi S, Aggarwal T, Kohli A. Operative management of fracture of shaft humerus by dynamic compression plate versus interlocking intramedullary nailing: A comparative prospective study of 30 cases. Med J DY Patil Univ. 2013; 6(1):49.

5. Rockwood Green's - Fractures in Adults. In: and others, editor. 8th Edn.. vol. 1; 2015. p. 1087.

6. Schatzker J, Tile M. The rationale of operative fracture care . In: 3rd Edn.. vol. 15. Springer International.

7. Heim D, Herkert F, Hess P, Regazzoni P. Surgical treatment of humeral shaft fractures. J Trauma. 1993;35(2):226-32. doi:10.1097/00005373- 199308000-00009.
8. Strong GT, Walls N, Queen MM. The epidemiology of humeral shaft fractures. JBJS(Br). 1998;80(2):249-53.

9. Lin J. Treatment of humeral shaft fractures with the humeral interlockednail and comparison with plate fixation . J Trauma . 1998;44(5):854-9.

10. Foster RJ, Foster GL, Dixon AW, Bach RW, Appleyard TM. GreenInternalFixation of Fractures \& Non-Unions of the Humeral Shaft. JBJS(Am). 1985;67(6):857-64.

11. Singh P, Gandhi V, Bansal D. Comparative Study of Compression Plating vs Interlocking Nail in Fracture Shaft of Humerus. IJCMR. 2016;3(11):3385-8.

12. Lin J. Treatment of humeral shaft fractures with the humeral interlockednail and comparison with plate fixation . J Trauma . 1998;44(5):854-9.

13. Naveen P., Chaitanya P. "comparative study between the dynamic compression plating (dcp) and the intramedullary interlocking nailing in diaphyseal fractures of the humerus in adults" Journal of Evolution of Medical and Dental Sciences/ 2 (45O 11:11; $2013: 8705-12$.

14. Dabezies EJ, Banta CJ, Murphy CP, d'Ambrosia RD. Plate fixation of the humeral shat for acute fractures with or without radial nerve injuries. J Orthop Trauma: 1992:6:10-13.

15. McCormack RG, Brien D, Buckley RE, McKee MD, Powell J, Schemitsch EH. Fixation of fractures of the shaft of the humerus by dynamic compression plate or intramedullary nail. A prospective, randomised trial. J Bone Joint Surg $\mathrm{Br}$ 2000;82:336-9.

16. Watanabe RS. Intramedullary fixation of complicated fractures of humeral shaft. Clin Orthop Relat Res 1993;292:255-63.

17. Garcia AJ, Maeck BH. Radial nerve injuries in the fractures of the shaft of the humerus. Am J Surg. 1960:99:625-627. 
18. Kettlekamp DB, Alexander H. Clinical review of radial nerve injury. $\mathrm{J}$ trauma. 1967:7:424-432.

19. K Ram Mohan, K Kishore Kumar,J Venkateshwarlu, el al,. "Comparative study of functional outcome of dynamic compression plating and interlocking nailing for fracture shaft of humerus in adults" / PJMS-2021;11(1):89-98.

20. Bell M.J, Beauchamp, Kellam JK and McMurtry. The Results of Plating Humeral Shaft Fractures in Patients with Multiple Injuries, the Sunny Brook Experience. JBJS Am 1985; Vol - 67; 293- 296. 